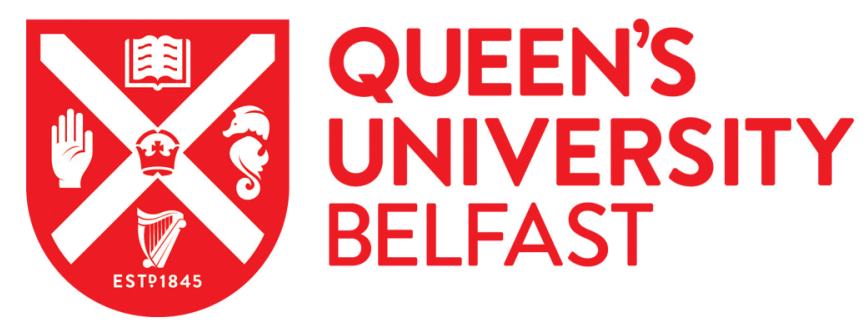

\title{
Luminescent lanthanide cyclen-based enzymatic assay capable of diagnosing the onset of catheter-associated urinary tract infections both in solution and within polymeric hydrogels
}

Surender, E. M., Bradberry, S. J., Bright, S. A., McCoy, C. P., Williams, D. C., \& Gunnlaugsson, T. (2017). Luminescent lanthanide cyclen-based enzymatic assay capable of diagnosing the onset of catheter-associated urinary tract infections both in solution and within polymeric hydrogels. Journal of the American Chemical Society, 139(1), 381-388. https://doi.org/10.1021/jacs.6b11077

\section{Published in:}

Journal of the American Chemical Society

\section{Document Version:}

Peer reviewed version

Queen's University Belfast - Research Portal:

Link to publication record in Queen's University Belfast Research Portal

\author{
Publisher rights \\ Copyright (C) 2016 American Chemical Society \\ This document is the Accepted Manuscript version of a Published Work that appeared in final form in Journal of the American Chemical \\ Society, copyright ( $)$ American Chemical Society after peer review and technical editing by the publisher. To access the final edited and \\ published work see http://pubs.acs.org/doi/abs/10.1021/jacs.6b11077
}

\section{General rights}

Copyright for the publications made accessible via the Queen's University Belfast Research Portal is retained by the author(s) and / or other copyright owners and it is a condition of accessing these publications that users recognise and abide by the legal requirements associated with these rights.

\section{Take down policy}

The Research Portal is Queen's institutional repository that provides access to Queen's research output. Every effort has been made to ensure that content in the Research Portal does not infringe any person's rights, or applicable UK laws. If you discover content in the Research Portal that you believe breaches copyright or violates any law, please contact openaccess@qub.ac.uk. 


\title{
Luminescent lanthanide cyclen-based enzymatic assay capable of diagnosing the onset of catheter-associated urinary tract infections both in solution and within polymeric hydrogels
}

\author{
Esther M. Surender, ${ }^{\dagger}$ Samuel J. Bradberry, ${ }^{\dagger}$ Sandra A. Bright ${ }^{\ddagger}{ }^{\ddagger}$ Colin P. McCoy, ${ }^{\S}$ D. Clive Williams ${ }^{\ddagger}$ \\ and Thorfinnur Gunnlaugsson*†
}

\begin{abstract}
†'School of Chemistry, Trinity Biomedical Sciences Institute (TBSI), Trinity College Dublin, The University of Dublin, Dublin 2, Ireland.

‡School of Biochemistry and Immunology, Trinity Biomedical Sciences Institute (TBSI), Trinity College Dublin, The University of Dublin, Dublin 2, Ireland.

§School of Pharmacy, Queen’s University Belfast, 97 Lisburn Road, Belfast, BT9 7BL, Northern Ireland, U.K.

KEYWORDS: Catheter, pH, lanthanide, urease, urea, luminescence, biofilm, hydrogel.
\end{abstract}

\begin{abstract}
Herein we present a supramolecular (delayed luminescent) Eu(III)-based pH-responsive probe/sensor with the ability to detect the urease-mediated hydrolysis of urea in aqueous solution. A series of photophysical titrations show this Eu(III) chelate behaves as an 'on-off' luminescent switching probe, with its luminescence being quenched upon urea being enzymatically converted into ammonia and carbon dioxide. Calculation of the rate constant (k) and activation energy (Ea) for this hydrolysis reaction are detailed; the results demonstrate a direct observation of enzymatic activity in solution by the sensor. The potential application of this probe in detecting the onset of catheter-associated urinary tract infections (CAUTIs) is also demonstrated by incorporating 1.Eu into water-permeable hydrogels that can be utilized as an alternative coating for catheters.
\end{abstract}

\section{INTRODUCTION}

Catheter-associated urinary tract infection (CAUTI) is one of the most common health-care associated infections worldwide, accounting for up to $40 \%$ of all nosocomial infections. ${ }^{1,2}$ Approximately $20 \%$ of all hospitalized patients are catheterized. ${ }^{2}$ Currently, the most commonly deployed prosthetic medical device is the Foley indwelling urethral catheter. ${ }^{1 \mathrm{~d}, 2 \mathrm{~b}}$ The development of CAUTIs has been directly linked to the duration of catheterization; nearly $100 \%$ of patients undergoing long-term catheterization ( $\geq 28$ days) are found to develop catheterassociated bacteriuria (CAB). ${ }^{\text {1a-c }}$ While most cases of $C A B$ are asymptomatic and do not require treatment, some individuals can experience symptomatic episodes of CAUTI, which can result in pyelonephritis, septicaemic or endotoxic shock, and ultimately death. . $^{\mathrm{l}, 2 \mathrm{~b}}$ These episodes are triggered by the occurrence of catheter encrustation, where the formation of crystalline polymicrobial-based biofilms on the inner and outer surface of the catheter tube causes the device to become blocked, and as such obstructs urinary flow. ${ }^{3}$ The bacterial species most associated with catheter encrustation and CAUTI are ureaseproducing microorganisms; specifically Proteus mirabilis, Proteus vulgaris, and Providencia rettgeri. ${ }^{1,2}$ Their ability to secrete urease, an enzyme that catalyzes the hydrolysis of urea (one of the primary constituents within urine) into ammonia and carbon dioxide, results in the $\mathrm{pH}$ of the urine being increased towards alkaline, which induces the precipitation of calcium and magnesium phosphate crystals from the urine. ${ }^{4}$ These crystals accumulate within the bacterial layers of the biofilm, making it highly crystalline with increased resistance to both the hosts immune system and to antibiotic treatment. . $^{3 a, 5}$ Several strategies have been employed to prevent the onset of CAUTI, the majority of which involve coating or impregnating the catheter material (hydrogels and other related soft materials) with antimicrobial agents that will counteract bacterial adhesion. ${ }^{1 \mathrm{c}, 2 \mathrm{za}}$ These agents include silver alloys, ${ }^{6}$ antibacterials, ${ }^{7}$ liposomes, ${ }^{8}$ and urease inhibitors. ${ }^{9}$ Nevertheless, no single prosthetic medical device currently exists that is able to completely inhibit $\mathrm{CAB}$ from developing during catheterization. Consequently, focus has turned to finding ways in which CAUTI can be quickly diagnosed in order to permit early treatment. The primary diagnostic tool currently utilized in the clinic to monitor $\mathrm{CAB}$ is the bromothymol

Scheme 1. Structural formula of the cationic complex 1.Eu

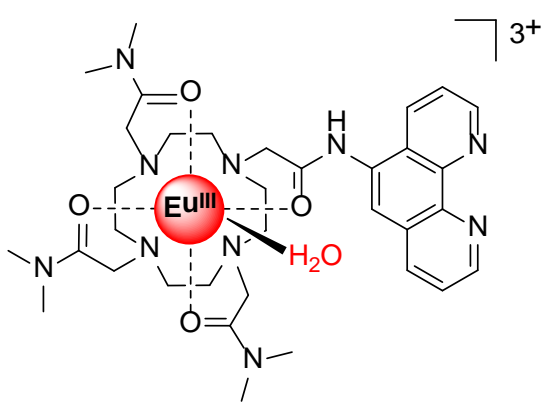


blue colorimetric sensor developed by Stickler, which changes from a yellow ( $\mathrm{pH} \mathrm{6)}$ to blue $(\mathrm{pH} \mathrm{8)}$ color in response to the $\mathrm{pH}$ of the urine being elevated by the presence of Proteus bacteria..$^{10}$ Herein we describe an alternative route for diagnosing the onset of CAUTI through the use of a lanthanide-based $(\mathrm{Ln}(\mathrm{III})) \mathrm{pH}$-responsive luminescent probe (1.Eu, Scheme 1), which in combination with the enzyme urease, can monitor the hydrolysis of urea (either in solution or within a biocompatible material) in real time.

As we and others have demonstrated, lanthanide luminescence is a powerful analytical tool that can be exploited for sensing and imaging biological systems. ${ }^{11}$ In particular, we have shown that such luminescent probes can be employed for observing enzymatic reactions in solution in real-time. ${ }^{12}$ This includes the development of glycosylated Ln(III)-based cyclen complexes for monitoring glycosidase enzyme activity and $\mathrm{Tb}(\mathrm{III})$-based cyclen maleimide complexes for monitoring glutathione reductase. ${ }^{12 a, b}$ In addition, we have also designed several Ln(III)based $\mathrm{pH}$-responsive luminescent sensors, ${ }^{13}$ some of which were developed to mimic logic gate operations ${ }^{14 a, b}$, while others were conjugated to gold nanoparticles. ${ }^{14, \mathrm{~d}}$

One example of such a $\mathrm{pH}$ responsive design is the $\mathrm{Eu}(\mathrm{III})$ cyclen complex 1.Eu; a highly water soluble coordinatively unsaturated octadentate (cationic) complex possessing a single axial metal bound water molecule. This system functions as a reversible luminescent 'off-on-off sensor within the $\mathrm{pH}$ range of $2-10$. The $\mathrm{pH}$-dependent nature of this triacetamide-substituted cyclen derivative arises from the covalently attached 1,10-phenanthroline (phen), which functions as an antenna for populating the ${ }^{5} \mathrm{D}_{4} \mathrm{ex}-$ cited state of Eu(III). ${ }^{15}$ Specifically, we have demonstrated that the phosphorescent emission of 1.Eu has a bellshaped $\mathrm{pH}$ dependency; corresponding to the $\mathrm{pH}$ values of $2-4,5-7$, and $8-10 .{ }^{15 c}$ We therefore anticipated that 1.Eu could potentially be utilized as a spectroscopic 'onoff sensor/probe to detect the presence of ureasesecreting bacteria within urinary catheters. This could be achieved by impregnating water-permeable hydrogels, that could be used as an alternative coating material, with the complex 1.Eu. ${ }^{16}$ Through photophysical analysis, we demonstrated that this was indeed possible; the ureasemediated hydrolysis of urea results in the $\mathrm{pH}$ of the system being elevated and as such causes the metal-centered emission of 1.Eu to be quenched. Moreover, we show that the rate of this quenching increases at elevated temperature and upon increasing the quantity of enzyme units (U).

\section{RESULTS}

\section{Synthesis and characterization}

Both the synthesis and characterization of ligand $\mathbf{1}$ and its corresponding Eu(III) complex 1.Eu have been previously reported by us. ${ }^{15 a}$ The hydration state $(q)$ was determined by measuring the excited state lifetimes of 1.Eu in $\mathrm{H}_{2} \mathrm{O}$ and $\mathrm{D}_{2} \mathrm{O}$, with the number of metal bound water molecules in solution being confirmed as one (see Supporting Information, Figure S1). ${ }^{15 a}$

\section{Luminescent stability of 1 .Eu in solution}

Population of the Eu(III) excited state was achieved by indirect excitation of the phen antenna, which was confirmed upon recording the time-delayed emission and excitation spectra of $\mathbf{~}$.Eu.

The luminescence response of $\mathbf{1}$.Eu $\left(1 \times 10^{-5} \mathrm{M}\right)$, in the absence and presence of either urea or urease, was monitored in $\mathrm{H}_{2} \mathrm{O}$ over $24 \mathrm{~h}$. Since the normal concentration range of urea in human blood plasma is between 3.0 - 6.5 $\times 10^{-3} \mathrm{M}$ and urease behaves as a catalyst, concentrations of $2.3 \times 10^{-3} \mathrm{M}$ and $0.01-0.1 \mathrm{U}$ were utilized, respectively. As expected, five distinct phosphorescence transitions were observed at 58o, 593, 615, 654, 683, and $701 \mathrm{~nm}$ upon indirect excitation of 1.Eu at $266 \mathrm{~nm}$, which can be assigned to the ${ }^{5} \mathrm{D}_{\mathrm{o}} \rightarrow{ }^{7} \mathrm{~F}_{\mathrm{J}}(\mathrm{J}=\mathrm{o}-4)$ transitions of $\mathrm{Eu}(\mathrm{III})$, as shown in Figure 1. Indeed, the intensity of all five emission bands was seen to remain constant in aqueous solution at $22^{\circ} \mathrm{C}$, indicating $\mathbf{~}$.Eu was stable towards $\mathrm{Eu}(\mathrm{III})$ dissociation. Similarly, no changes in the luminescent properties of 1.Eu were exhibited when in the presence of urea $(2.3 \times$ $10^{-3} \mathrm{M}$ ) or urease (o.1 $\left.\mathrm{U}\right)$, with the metal-centered emission remaining 'switched on' for up to $24 \mathrm{~h}$ (see Supporting Information, Figure $\mathrm{S}_{2}-3$ ). Importantly, repeating these measurements at $37^{\circ} \mathrm{C}$ further showed that the luminescent properties of $\mathbf{~}$.Eu were not temperature dependent. Regardless of urea or urease being present, no
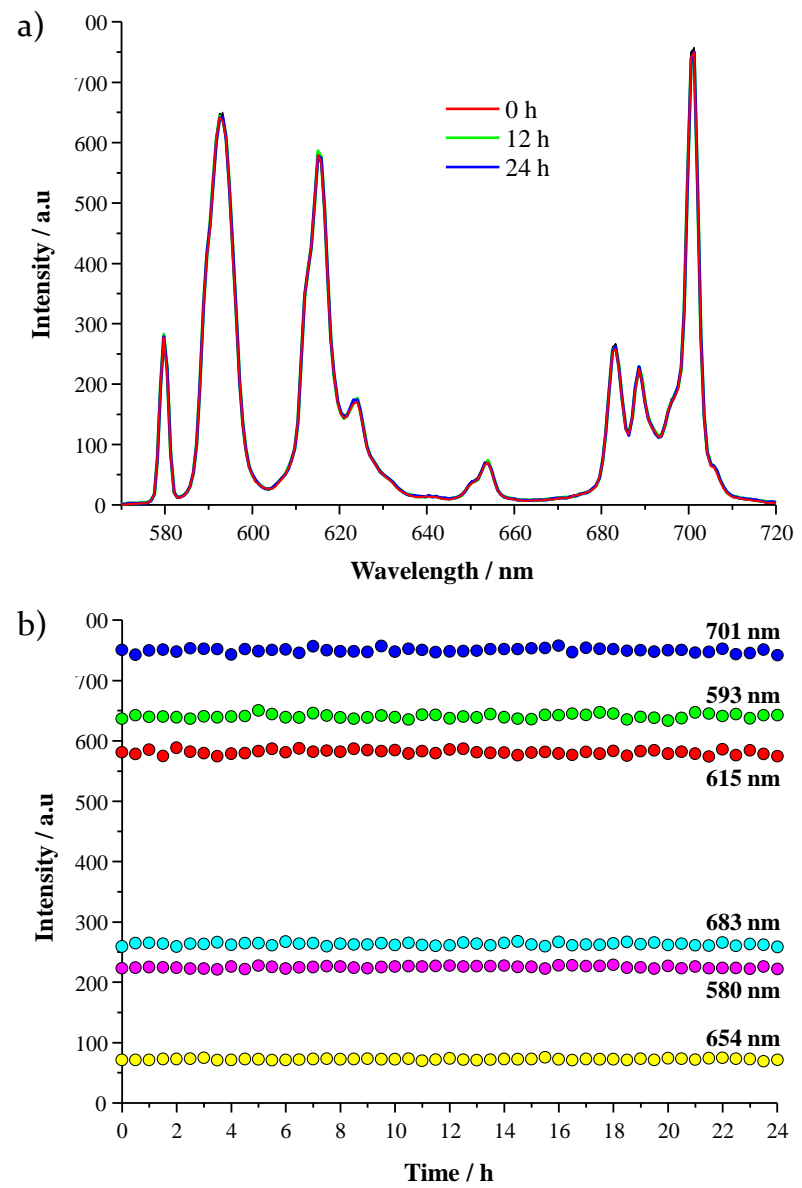

Figure 1. a) The phosphorescence spectrum of 1.Eu $\left(1 \times 10^{-5} \mathrm{M}\right)$ over multiple time points, recorded in $\mathrm{H}_{2} \mathrm{O}$ at $295 \mathrm{~K}\left(\lambda_{\text {exc }}=266\right.$ $\mathrm{nm})$. b) Changes in the Eu(III) emission as a function of time. 

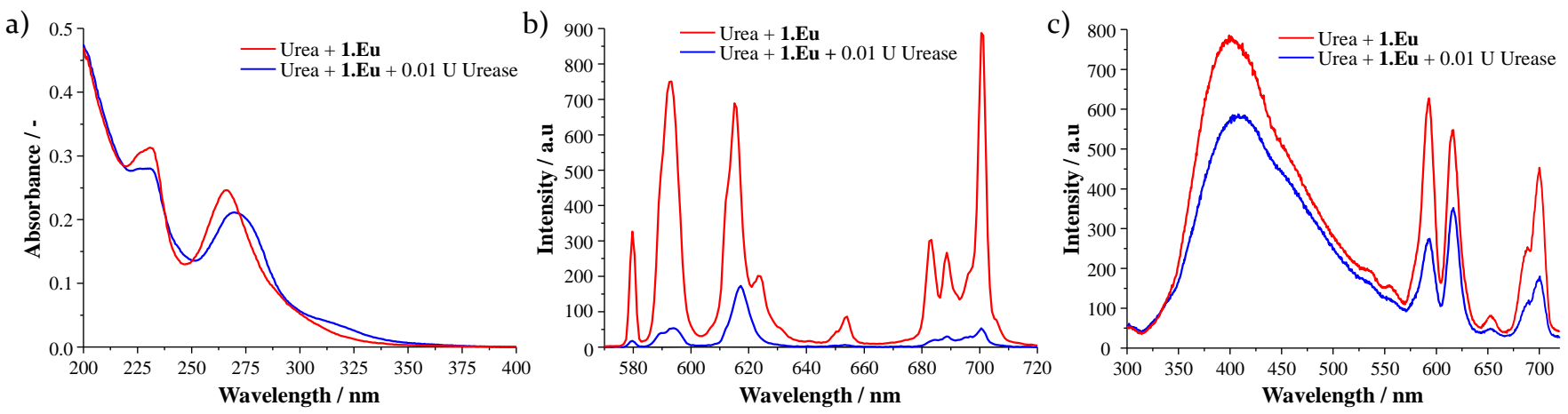

Figure 2. a) The UV-vis absorption, b) the phosphorescence, and c) the total emission spectrum of 1.Eu before and 60 min after the addition of $0.01 \mathrm{U}$ of urease, measured in an aqueous solution of urea $\left(2.3 \times 10^{-3} \mathrm{M}\right)$ at $295 \mathrm{~K}$.

variation was seen in the emission intensity (see Supporting Information, Figure $S_{4}-5$ ). These results therefore indicate that the $\mathrm{Eu}$ (III) emission is not dependent on the local environment of the $\mathrm{pH}$ sensor, which is important to establish with respect to incorporating the sensor into soft polymeric materials (e.g. hydrogels).

\section{Detecting the urease-mediated hydrolysis of urea pho- tophysically}

With the luminescent behavior of 1.Eu investigated independently with both urea and urease, we next determined whether 1.Eu could be utilized as a $\mathrm{pH}$-responsive probe to monitor the urease-mediated hydrolysis of urea. This was achieved by recording the photophysical properties of 1.Eu before and $60 \mathrm{~min}$ after the addition of urease (o.01 $0.10 \mathrm{U}$; increments of $0.01 \mathrm{U}$ ) at $22{ }^{\circ} \mathrm{C}$.

The ground state properties were firstly investigated; the UV-vis absorption spectra of $\mathbf{1}$.Eu was characteristic of substituted phen derivatives, consisting of two main bands centered at 230 and $266 \mathrm{~nm}$, which are assigned to the $\pi-\pi^{*}$ intra-ligand transitions of the antenna moiety. ${ }^{15}$ The addition of urease (o.o1 $\mathrm{U}$ ) to a solution of 1.Eu and urea resulted in the urea being rapidly hydrolyzed. This caused a marked bathochromic shift in the lower energy absorption band of the phen antenna $(266 \rightarrow 274 \mathrm{~nm})$ and the concomitant appearance of a small shoulder at $c a .312$ $\mathrm{nm}$, as shown in Figure 2a, with the appearance of several isosbestic points. This red shift corresponds with the changes exhibited in the $\mathrm{pH}$ titration previously reported by Leonard and co-workers, where upon increasing the $\mathrm{pH}$ from $5.5 \rightarrow 9.5$ the $\lambda_{\max }$ of the $266 \mathrm{~nm}$ band was seen to red shift by ca. $8 \mathrm{~nm} .{ }^{15 a}$ Moreover, this bathochromic shift was evident regardless of the units of urease added $(0.01 \rightarrow 0.10 \mathrm{U})$ to the solution of $\mathbf{1 . E u}$ and urea (see Supporting Information, Figure S6a).

Both the delayed lanthanide luminescence and the fluorescence spectra were obtained by exciting the same solution at $266 \mathrm{~nm}$. As anticipated, the $\mathrm{Eu}(\mathrm{III})$ emission was 'switched off' upon the addition of $0.01 \mathrm{U}$ of urease, with ca. 90\% quenching being observed after $60 \mathrm{~min}$, as demonstrated in Figure $2 \mathrm{~b}$; this being the direct result of the local $\mathrm{pH}$ environment of 1.Eu changing. Increasing the concentration of urease $(0.01 \rightarrow 0.10 \mathrm{U}$; 0.01 increments) added to 1.Eu resulted in the same amount of quenching in the $\mathrm{Eu}(\mathrm{III})$-centered emission being exhibited (see Supporting Information, Figure S6b). However, the rate at which the emission was 'switched off increased.

The changes observed in the fluorescence emission spectra of 1.Eu were much less dramatic; the intensity of the ligand fluorescence was reduced by $c a .40 \%$ and a redshift in the $\lambda_{\max }$ from 400 to $415 \mathrm{~nm}$ was observed following the addition of $0.01 \mathrm{U}$ of the enzyme, as shown in Figure $2 \mathrm{c}$. As before, no difference in the extent of quenching was seen upon increasing the quantity of units of urease added to 1.Eu (see Supporting Information, Figure S6c). Excitation spectra were also recorded before and after the addition of enzyme; all the spectra structurally matched those of the absorption spectra (see Supporting Information, Figure $\mathrm{S}_{7}$ ), and showed that the sensitization process from the antenna to the $\operatorname{Ln}(\mathrm{III})$ center was indeed modulated by the addition of enzyme and the resultant change in $\mathrm{pH}$. These results clearly demonstrate that 1.Eu can be used to observe the enzymatic catalyzed hydrolysis of urea in real time, even at micromolar concentrations.

\section{Determination of the rate constant $(\mathrm{k})$}

In order to quantify the enzymatic activity of urease in hydrolyzing the urea in solution into ammonia and carbon dioxide, the rate constant $(\mathrm{k})$ of this reaction was next calculated by plotting the quenching in the $\mathrm{Eu}(\mathrm{III})$ centered emission of $\mathbf{~}$.Eu as a function of time for all the ${ }^{5} \mathrm{D}_{\mathrm{o}} \rightarrow 7 \mathrm{~F}_{\mathrm{J}}(\mathrm{J}=\mathrm{O}-4)$ transitions.

The resulting titration profiles are given in Figure 3 and clearly show that the addition of a higher quantity of urease units results in the $\mathrm{Eu}(\mathrm{III})$ emission being quenched at a faster rate (see Supporting Information, Figure S8, for other transition bands). In general, all the $\mathrm{Eu}(\mathrm{III})$ centered emission bands were quenched to the same extent (up to $90 \%$ ) ca. 6o, 20, and 15 min after the addition of $0.01-0.02,0.03-0.04$, and $0.05-0.10 \mathrm{U}$ of urease, respectively. Fitting this luminescent quenching to a monoexponential function allowed for the rate constant value to be determined for each of the ${ }^{5} \mathrm{D}_{0} \rightarrow{ }^{7} \mathrm{~F}_{\mathrm{J}}$ transitions within the enzymatic unit range of $0.01-0.1 \mathrm{U}$. As shown in Figure 4, the rate constant was seen to linearly increase as a function of urease activity, with the lowest and highest $\mathrm{k}$ values being given for 0.01 and $0.10 \mathrm{U}$ of urease, respectively. This first-order relationship, where the rate of reaction was seen to be directly proportional to the concentration of urease, demonstrated that the higher the quantity of urease units added to the urea and 1.Eu solution, 

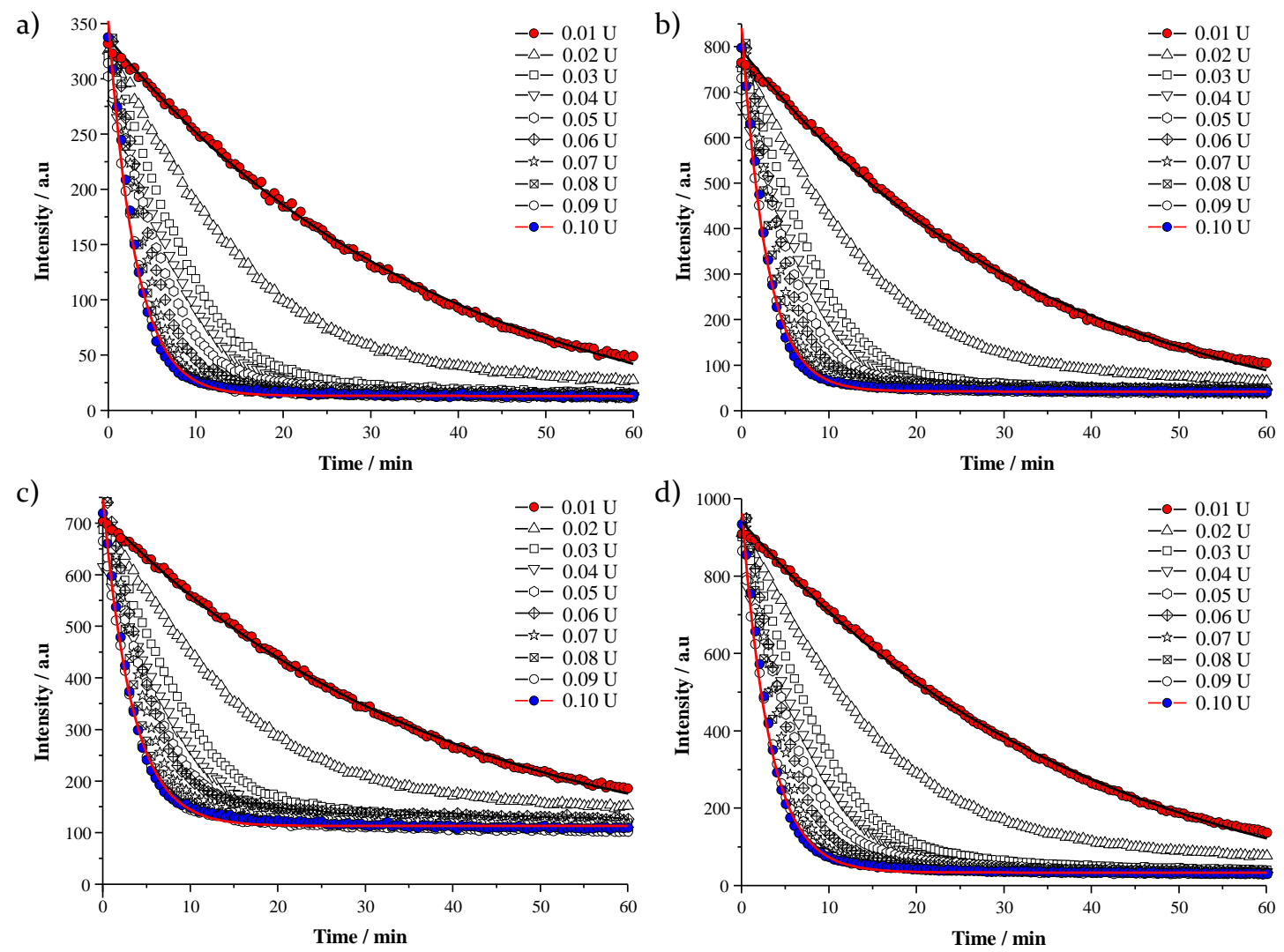

Figure 3. Changes in the delayed-Eu(III) emission of 1.Eu $\left(1 \times 10^{-5} \mathrm{M}\right)$ as a function of time in an aqueous solution of urea $\left(2.3 \times 10^{-3}\right.$ M) at $295 \mathrm{~K}\left(\lambda_{\text {exc }}=266 \mathrm{~nm}\right)$, measured at a) $580 \mathrm{~nm}$, b) $593 \mathrm{~nm}$, c) $615 \mathrm{~nm}$, and d) $701 \mathrm{~nm}$ upon the addition of urease (0.01 - $\left.0.10 \mathrm{U}\right)$.

the greater the decrease exhibited in the activation energy of the reaction, and the faster the rate of hydrolysis.

The effect of temperature on the rate of hydrolysis was also studied by repeating the above measurements at both 30 and $37^{\circ} \mathrm{C}$ (see Supporting Information, Figure S9 - 10). At elevated temperatures the $\mathrm{Eu}(\mathrm{III})$-centered emission became 'switched off much more rapidly. More than 90\% quenching in the phosphorescence of 1.Eu occurred $45,20,10$, and 5 min after the addition of $0.01,0.02,0.03-$ 0.05 , and $0.06-0.08 \mathrm{U}$ of urease, respectively, when at 37

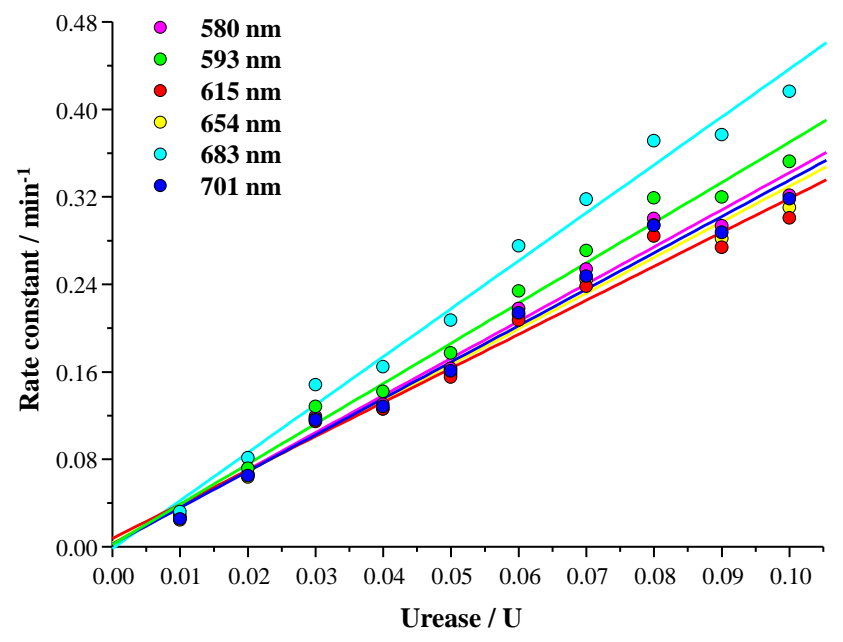

Figure 4. Changes in the rate of hydrolysis of urea as a function of urease units at $295 \mathrm{~K}$, calculated from the quenching in Eu(III)emission of 1.Eu (shown in Figure 3), with all linear fits obtained having a $\mathrm{R}^{2} \geq 0.98$.
${ }^{\circ} \mathrm{C}$ (see Supporting Information, Figure S10). Indeed, increasing either the temperature or the quantity of enzyme units added to the solution of 1.Eu and urea gave rise to a higher rate constant, whereby $\mathrm{k}^{37^{\circ} \mathrm{C}}>\mathrm{k}^{30^{\circ} \mathrm{C}}>\mathrm{k}^{22^{\circ} \mathrm{C}}$ and $\mathrm{k}^{0.1 \mathrm{U}}$ $>\mathrm{k}^{\mathrm{o} .01 \mathrm{U}}$ of enzyme (see Supporting Information, Figure S11). This can be explained by the fact that the enzymatic activity of urease increases as a function of temperature, with the optimal temperature of urease being known to be $60{ }^{\circ} \mathrm{C} .{ }^{17}$ As such, the conversion of urea into ammonia and carbon dioxide occurs at a quicker rate at higher temperatures, and in turn causes the $\mathrm{pH}$ of the system to also change at a much faster rate, ${ }^{18}$ which is observed by the $\mathrm{Eu}(\mathrm{III})$ probe. Hence, $\mathbf{1 . E u}$ in combination with urea, can be employed in a luminescent assay to monitor enzymatic hydrolysis reactions in real time in solution.

Determination of the activation energy $\left(E_{a}\right)$ from the Arrhenius Equation

Having established a relationship between the rate of hydrolysis of urea and temperature, the activation energy $\left(E_{a}\right)$ of this reaction was next calculated by utilizing the Arrhenius equation $\left[\ln (\mathrm{k})=\ln (\mathrm{A})-\mathrm{E}_{\mathrm{a}} / \mathrm{RT}\right] .{ }^{19}$ Plotting the rate constant as a function of $1 / T$ for all the ${ }^{5} \mathrm{D}_{\mathrm{o}} \rightarrow{ }^{7} \mathrm{~F}_{\mathrm{J}}(\mathrm{J}=\mathrm{o}$ - 4) transitions resulted in a negative linear correlation being evidenced in all four of the Arrhenius plots, with $\ln (\mathrm{k})$ decreasing as the quantity of urease was increased by $0.01 \mathrm{U}$ intervals between 0.02 - $0.05 \mathrm{U}$ (see Supporting Information, Figure S12). The average values obtained for $\mathrm{E}_{\mathrm{a}}$ (activation energy) and A (pre-exponential factor) are presented in Table 1 for each enzymatic unit. Indeed, both the mean $\mathrm{E}_{\mathrm{a}}$ and $\mathrm{A}$ for the urease-mediated hydrolysis 
reaction of urea were found to correlate well with reported literature, with an average value of $44.9 \mathrm{kJmol}^{-1}$ and 1.4 $\times 10^{7} \mathrm{~min}^{-1}$ being calculated for each, respectively. ${ }^{20}$ This relatively low value for the $E_{a}$ indicates that the hydrolysis of urea proceeds at a rapid rate in solution. This means the $\mathrm{pH}$ of the solution changes at a fast rate and as such explains the dramatic quenching exhibited for 1.Eu.

\section{$I C_{50}$ toxicity studies of 1 . Eu and urea}

With the intention of incorporating this Eu(III)-based pH-responsive probe into biomaterials that are currently utilized for catheters and the attached urinary collection bags, we next investigated the cytotoxicity properties of 1.Eu in vitro. Both the complex 1.Eu and urea were found to be relatively low in toxicity and potency, with an $\mathrm{IC}_{50}$ value of $200 \mu \mathrm{M}$ and $10 \mathrm{mM}$ being given for each, respectively (see Supporting Information, Figure S13). These high $\mathrm{IC}_{50}$ values suggest that prosthetic medical devices, such as catheters, impregnated with 1.Eu would not be expected to have any major negative impact on a patients' health or body.

Table 1. Summary of the activation energy and preexponential factor for the urease-mediated hydrolysis of urea in aqueous solution, determined from the quenching in $\mathrm{Eu}(\mathrm{III})$ emission of 1.Eu.

\begin{tabular}{ccc}
\hline Urease / U & $\mathrm{E}_{\mathrm{a}} / \mathrm{kJmol}^{-1}$ & $\mathrm{~A} / \mathrm{min}^{-1}$ \\
\hline 0.02 & $46.7 \pm 2.3$ & $3.2 \times 10^{7} \pm 140$ \\
0.03 & $42.9 \pm 2.8$ & $5.2 \times 10^{6} \pm 190$ \\
0.04 & $43.1 \pm 2.9$ & $4.5 \times 10^{6} \pm 180$ \\
0.05 & $46.8 \pm 3.4$ & $1.3 \times 10^{7} \pm 220$ \\
\hline
\end{tabular}

\section{Water-permeable hydrogels impregnated with 1.Eu}

Having studied the photophysical properties of $\mathbf{1 . E u}$ in solution, we next turned our attention towards forming soft luminescent biomaterials; the intention being that they could be utilized as diagnostic materials to detect the onset of CAUTIs.

With this in mind, the complex 1.Eu was non-covalently impregnated within water-permeable hydrogels using a poly(HEMA) matrix, which was prepared according to our previously published methodology.14a,16 A homogenous solution of HEMA, EGDMA, and 1.Eu were polymerized under free-radical polymerization using AIBN to afford a hard brittle acrylic monolith with the complex encapsulated $(0.033 \% \mathrm{w} / \mathrm{w})$. The monolith was then swelled in deionized water to yield soft polymer hydrogel materials of 1.Eu, which were transparent to the naked eye under ambient light and red emissive upon irradiation at $\mathbf{2 5 4}$ $\mathrm{nm}$, as is evident from Figure 5 .

As anticipated, the characteristic spectroscopic properties of complex 1.Eu were retained upon encapsulation within
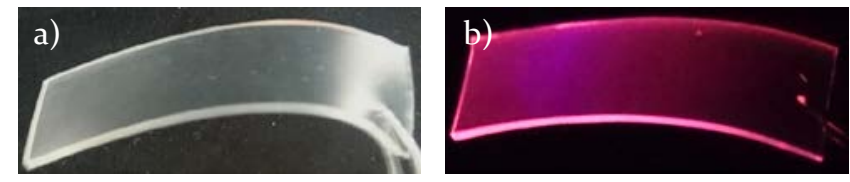

Figure 5. Photographs of the hydrogels encapsulated with 1.Eu and swelled in deionized $\mathrm{H}_{2} \mathrm{O}$. Images were captured a) under ambient light and b) upon irradiation at $254 \mathrm{~nm}$. the hydrogel. The Eu(III)-centered emission spectra, which was obtained by suspending the swelled gel (30 $\mathrm{mm} \times 10 \mathrm{~mm} \times 1.2 \mathrm{~mm}$ ) in a stirred solution of Millipore $\mathrm{H}_{2} \mathrm{O}$, matched exactly with that observed for 1.Eu in solution (Figure 6; c.f 1.Eu (Hydrogel)); this suggests that the coordination environment of the $\mathrm{Eu}(\mathrm{III})$ ion was not substantially changed by the polymeric matrix. Furthermore,
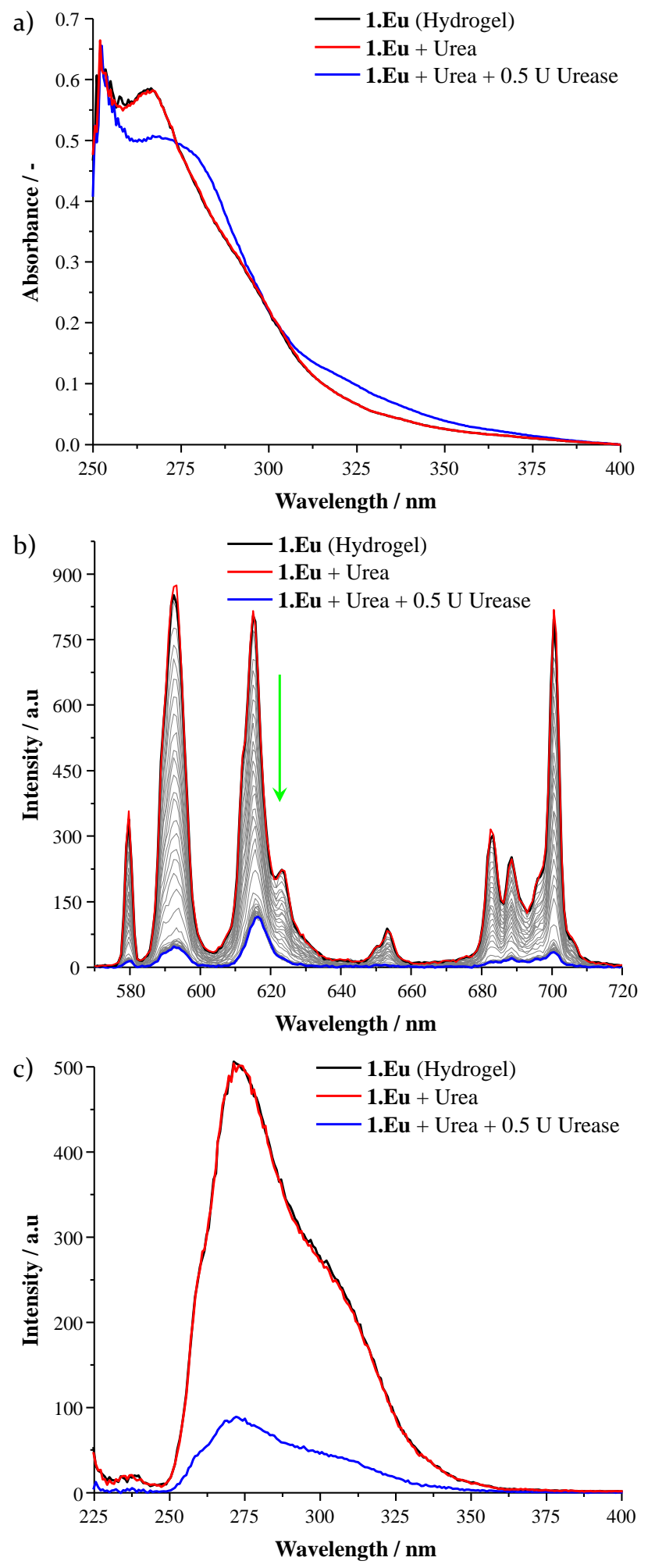

Figure 6. The a) UV-vis absorption, b) phosphorescence, and c) excitation spectra of the swelled 1.Eu-based hydrogel, before and 200 min after the addition of $0.5 \mathrm{U}$ of urease, measured in an aqueous solution of urea $\left(2.3 \times 10^{-3} \mathrm{M}\right)$ at $295 \mathrm{~K}$. 


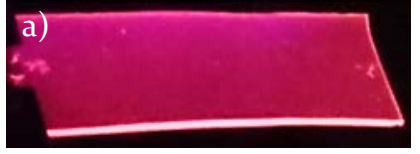

Figure 7. Photographs of the a) 'on' and b) 'off' state of the hydrogel, when irradiated at $\lambda_{\max }=254 \mathrm{~nm}$. Left image was acquired before the addition of urease and the right image $200 \mathrm{~min}$ after.

the UV-vis absorption and excitation spectra of these hydrogels also correlated with the results obtained in solution, with the main $\pi-\pi^{*}$ band at $266 \mathrm{~nm}$ being clearly exhibited in both cases (Figure 6; c.f 1.Eu (Hydrogel)).

To ascertain whether these luminescent hydrogels were also $\mathrm{pH}$-responsive, their ability to monitor the hydrolysis of urea into carbamic acid and sense the associated change in $\mathrm{pH}$ from acidic to basic, was studied. As with the solution studies, the photophysical parameters of the gel were recorded both before and 200 min after the addition of urease (0.5 $\mathrm{U})$ at $22{ }^{\circ} \mathrm{C}$, using urea as the supernatant. Both the UV-vis absorption and luminescence spectra coincided with that observed in solution for 1.Eu, as shown in Figure 6; the $\pi-\pi^{*}$ band in the UV-vis was once again red shifted by $c a$. $10 \mathrm{~nm}$, while the $\mathrm{Eu}(\mathrm{III})$-centered emission was quenched by over $85 \%$. This 'on-off response was also visible to the naked eye under UV light, where by the gel was seen to change from being predominantly bright red (on) to a faint pink/purple (off) color upon hydrolysis of the urea in solution, which is evident from Figure 7. Repetition of these measurements using a
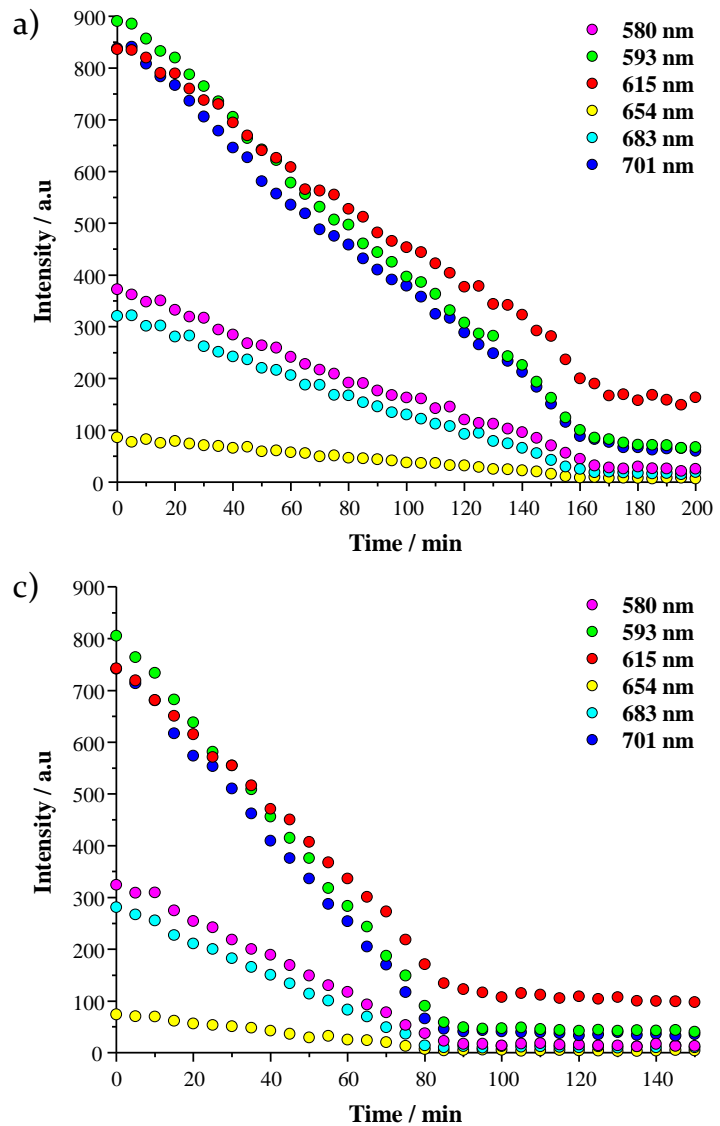

higher concentration of enzyme (1.o U) and an elevated temperature $\left(37^{\circ} \mathrm{C}\right)$ resulted in exactly the same spectroscopic trends being evidenced (see Supporting Information, Figure $\mathrm{S}_{4}-19$ ). However, the rate at which the $\mathrm{Eu}$ (III) emission was 'switched off varied. Increasing both the enzyme $(0.5 \rightarrow 1.0 \mathrm{U})$ and the substrate concentration $\left(2.3 \times 10^{-3} \rightarrow 10 \times 10^{-3} \mathrm{M}\right.$ of urea) gave rise to a faster rate of hydrolysis, and consequently increased the rate of luminescent decay exhibited for the hydrogel by 1.5 fold (see Figure 8). Furthermore, raising the temperature of the system to physiological temperature $\left(37^{\circ} \mathrm{C}\right)$ also caused the rate of quenching to substantially increase, with the 'on-off' response being observed in less than 6o min (see Supporting Information, Figure S2o). Unlike the solution studies, which are instantaneous, the response time of the hydrogels are diffusion controlled..$^{14 a, 16}$ As such, diffusion of the substrate and enzyme into the hydrogel matrix depends on the ambient conditions, as well as both the gels thickness (diffusion length) and surface area (accessible pores). While this response time is slower than that exhibited in solution, it is still relatively fast, which signifies the potential of this design for clinical use.

To ensure that these hydrogels were robust and that the complex did not leech out of the polymeric matrix, we also recorded the emission spectra of the supernatant solution over a 2 week period. Only a negligible amount of leeching of 1.Eu from the cross-linked matrix occurred at room temperature (see Supporting Information, Figure S21 - 22), indicating that the complex was indeed retained
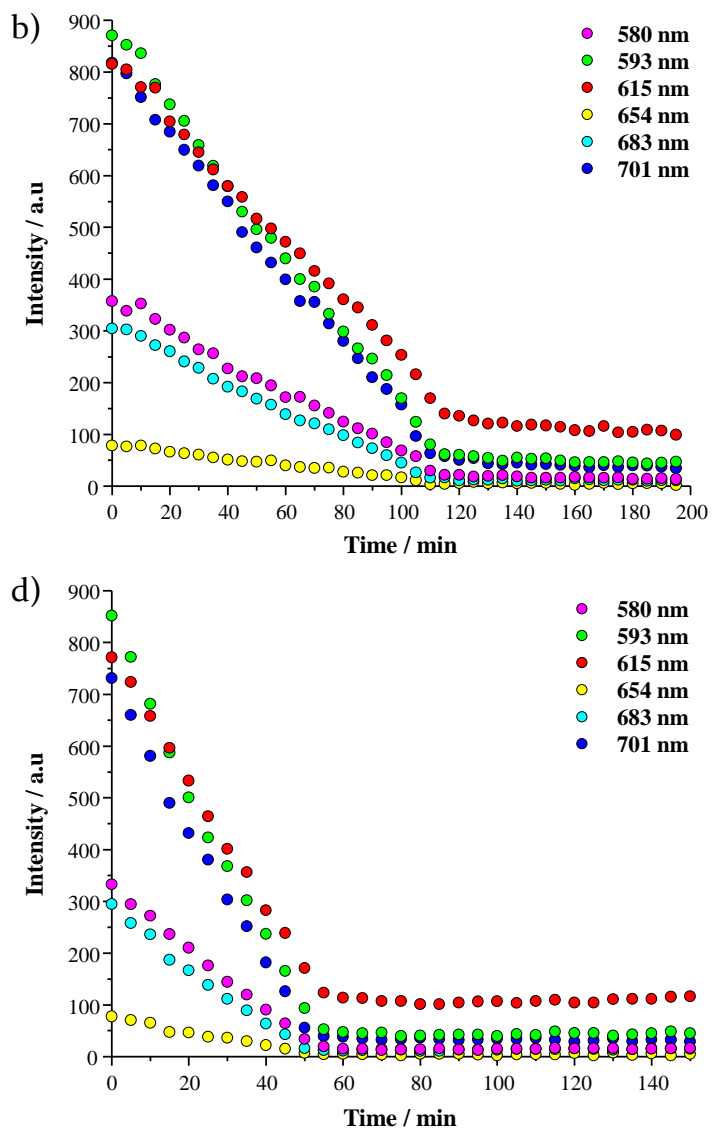

Figure 8. Changes in the delayed-Eu(III) emission of the swelled 1.Eu-based hydrogel as a function of time in an aqueous solution of urea at $295 \mathrm{~K}\left(\lambda_{\text {exc }}=266 \mathrm{~nm}\right)$, measured at $580 \mathrm{~nm}, 593 \mathrm{~nm}, 615 \mathrm{~nm}, 654 \mathrm{~nm}, 683 \mathrm{~nm}$, and $701 \mathrm{~nm}$ upon the addition of urease. Concentrations of urea and urease utilized were a) $\left.2.3 \times 10^{-3} \mathrm{M}, 0.5 \mathrm{U}, \mathrm{b}\right) 2.3 \times 10^{-3} \mathrm{M}, 1.0 \mathrm{U}$, c) $10 \times 10^{-3} \mathrm{M}, 0.5 \mathrm{U}$, and d) $10 \times 10^{-3} \mathrm{M}, 1.0 \mathrm{U}$. 
within the hydrogel. However, under physiological conditions $\left(37^{\circ} \mathrm{C}\right)$ the complex slowly leeched out into the supernatant solution; a gradual, but minimal increase in the metal-centered emission of the supernatant was observed for 7 days, after which the intensity plateaued (see Supporting Information, Figure S23 - 24).

\section{CONCLUSIONS}

In this article, we report on the development and application of a $\mathrm{pH}$-responsive luminescent probe that can be impregnated within soft polymer-based hydrogels to signal both biofilm formation and encrustation within catheters in the clinic. Specifically, we have demonstrated that this $\mathrm{Eu}(\mathrm{III})$ - based macrocyclic probe, $\mathbf{1 . E u}$, is capable of detecting the $\mathrm{pH}$ changes associated with the enzymatic hydrolysis of urea both in solution and when encapsulated within hydrogels. In particular, this system has been shown to behave in an 'on-off' responsive manner; as the urea is hydrolyzed to ammonia, the $\mathrm{pH}$ of the system changes from being mildly acidic to neutral/slightly alkaline, and hence results in the luminescence of 1.Eu being quenched. Although the gel studies were only conducted as a means of providing proof of concept, the response time of the materials was relatively quick, especially under physiological conditions. These preliminary results highlight the potential these materials have as diagnostic agents; a study that we are currently initiating.

\section{ASSOCIATED CONTENT}

Synthetic details, characterization, additional spectroscopic data for both the in solution and hydrogel studies. This material is available free of charge via the Internet at http://pubs.acs.org.

\section{AUTHOR INFORMATION}

\section{Corresponding Author}

*gunnlaut@tcd.ie

\section{Author Contributions}

The manuscript was written through contributions of all authors. / All authors have given approval to the final version of the manuscript. /

Notes

Any additional relevant notes should be placed here.

\section{ACKNOWLEDGMENT}

We thank the Irish Research Council (IRC) and the School of Chemistry TCD for the funding of a postgraduate scholarship (to EMS) and the Science Foundation Ireland (SFI) for the PI 2010 (10/IN.1/B2999) and PI 2013 (13/IA/1865) grants (to TG).

\section{ABBREVIATIONS}

CAUTI, catheter-associated urinary tract infection; CAB, catheter-associated bacteriuria; phen, 1,10-phenanthroline; Ln(III), lanthanide; Ea, Activation energy; A, pre-exponential factor; HEMA, 2-hydroxyethyl methacrylate; EGDMA, Ethylene glycol dimethacrylate; AIBN, azobisisobutyronitrile.

\section{REFERENCES}

1. (a) Siddiq, D. M.; Darouiche, R. O. Nat. Rev. Urol. 2012, 9, 305314. (b) Armbruster, C. E.; Mobley, H. L. T. Nat. Rev. Microbiol. 2012, 10, 743-754. (c) Jacobsen, S.; Stickler, D.; Mobley, H.; Shirtliff, M. Clin. Microbiol. Rev. 2008, 21, 26-59. (d) Irwin, N.
J.; McCoy, C. P.; Jones, D. S.; Gorman, S. P. Pharm. Res. 2013 30, 857-865.

2. (a) Soto, S. M. Adv. Biol. 2014, 2014, 1-13. (b) Stickler, D. In Coatings for Biomedical Applications; Driver, M., Ed.; Woodhead Publishing Ltd.: Cambridge, 2012, p 304.

3. (a) Kowalczuk, D.; Ginalska, G.; Golus, J. Int. J. Pharm. 2010, 402, 175-183. (b) Cadieux, P.; Wignall, G.; Carriveau, R. In Biomaterials and Tissue Engineering in Urology; Woodhead Publishing Ltd. : Cambridge, 2009, p 1.

4. (a) Stickler, D. J.; Jones, S. M.; Adusei, G. O.; Waters, M. G. J. Clin. Microbiol. 2006, 44, 1540-1542. (b) Shaw, G.; Choong, S.; Fry, C. Urol. Res. 2005, 33, 17-22. (c) Kosikowska, P.; Berlicki, Ł. Expert Opin. Ther. Pat. 2011, 21, 945-957. (d) Mobley, H.; Island, M. D.; Hausinger, R. P. Microbiol. Rev. 1995, 59, 451-480.

5. (a) Jacobsen, S. M.; Shirtliff, M. E. Virulence 2011, 2, 460-465. (b) Morris, N. S.; Stickler, D. J.; McLean, R. J. C. World J. Urol. 1999, 17, 345-350.

6. (a) Bologna, R. A.; Tu, L. M.; Polansky, M.; Fraimow, H. D.; Gordon, D. A.; Whitmore, K. E. Urology 1999, 54, 982-987. (b) Ahearn, D. G.; Grace, D. T.; Jennings, M. J.; Borazjani, R. N.; Boles, K. J.; Rose, L. J.; Simmons, R. B.; Ahanotu, E. N. Curr. Microbiol. 2000, 41, 120-125.

7. (a) Kowalczuk, D.; Przekora, A.; Ginalska, G. Mater. Sci. Eng., C 2015, 49, 274-280. (b) Kowalczuk, D.; Ginalska, G.; Przekora, A. J. Biomed. Mater. Res., Part A 2011, 98A, 222-228. (c) Darouiche, R. O.; Smith Jr, J. A.; Hanna, H.; Dhabuwala, C. B.; Steiner, M. S.; Babaian, R. J.; Boone, T. B.; Scardino, P. T.; Thornby, J. I.; Raad, I. I. Urology 1999, 54, 976-981.

8. (a) Shunmugaperumal, T.; Kaur, V.; Thenrajan, R. In Biofilmbased Healthcare-associated Infections; Donelli, G., Ed.; Springer International Publishing, Switzerland: 2015; Vol. 831, p 147. (b) DiTizio, V.; Ferguson, G. W.; Mittelman, M. W.; Khoury, A. E.; Bruce, A. W.; DiCosmo, F. Biomaterials 1998, 19, 18771884. (c) Pugach, J. L.; DiTizio, V.; Mittelman, M. W.; Bruce, A. W.; DiCosmo, F.; Khoury, A. E. J. Urol. 1999, 162, 883-887.

9. (a) Morris, N. S.; Stickler, D. J. Urol. Res. 1998, 26, 275-279. (b) Khan, K. M.; Iqbal, S.; Lodhi, M. A.; Maharvi, G. M.; Ullah, Z.; Choudhary, M. I.; Rahman, A.-u.; Perveen, S. Bioorg. Med. Chem. 2004, 12, 1963-1968. (c) Khan, K. M.; Naz, F.; Taha, M.; Khan, A.; Perveen, S.; Choudhary, M. I.; Voelter, W. Eur. J. Med. Chem. 2014, 74, 314-323. (d) Adsul, L. K.; Bandgar, B. P.; Chavan, H. V.; Jalde, S. S.; Dhakane, V. D.; Shirfule, A. L. J. Enzyme Inhib. Med. Chem. 2013, 28, 1316-1323.

10. (a) Stickler, D. J.; Jones, S. M.; Adusei, G. O.; Waters, M. G.; Cloete, J.; Mathur, S.; Feneley, R. C. L. BJU Int. 2006, 98, 12441249. (b) Milo, S.; Thet, N. T.; Liu, D.; Nzakizwanayo, J.; Jones, B. V.; Jenkins, A. T. A. Biosens. Bioelectron. 2016, 81, 161-172. (c) Malic, S.; Waters, M. G. J.; Basil, L.; Stickler, D. J.; Williams, D. W. J. Biomed. Mater. Res., Part B 2012, 100B, 133-137. (d) Long, A.; Edwards, J.; Thompson, R.; Lewis, D. A.; Timoney, A. G. BJU Int. 2014, 114, 278-285.

11. (a) Surender, E. M.; Comby, S.; Cavanagh, B. L.; Brennan, O.; Lee, T. C.; Gunnlaugsson, T. Chem 2016, 1, 438-455. (b) Chang, C. J.; Gunnlaugsson, T.; James, T. D. Chem. Soc. Rev. 2015, 44, 4176-4178. (c) Chang, C. J.; Gunnlaugsson, T.; James, T. D. Chem. Soc. Rev. 2015, 44, 4484-4486. (d) Amoroso, A. J.; Pope, S. J. A. Chem. Soc. Rev. 2015, 44, 4723-4742. (e) Heffern, M. C.; Matosziuk, L. M.; Meade, T. J. Chem. Rev. 2014, 114, 44964539. (f) Butler, S. J.; Delbianco, M.; Lamarque, L.; McMahon, B. K.; Neil, E. R.; Pal, R.; Parker, D.; Walton, J. W.; Zwier, J. M. Dalton Trans. 2015, 44, 4791-4803; (g). Surender, E. M.; Comby, S.; Martyn, S.; Cavanagh, B.; Lee, T. C.; Brougham, D. F.; Gunnlaugsson, T. Chem. Commun. 2016, 52, 10858-10861. (h) Caffrey, D. F.; Gunnlaugsson, T. Dalton Trans. 2014, 43, 17964-17970. (i) Plush, S. E.; Gunnlaugsson, T. Org. Lett., 2007, 9, 1919-1922. (j) Banerjee, S.; Kandanelli, R.; Bhowmik, S.; Maitra, U. Soft Matter, 2011, 7, 8207-8215.

12. (a) Burke, H. M.; Gunnlaugsson, T.; Scanlan, E. M. Org. Biomol. Chem., 2016, 14, 9133-9145. (b) McMahon, B. K.; Gunnlaugsson, T. J. Am. Chem. Soc. 2012, 134, 10725-10728. (c) Bhowmika, S.; Maitra, U. Chem. Commun., 2012, 48, 4624-4626. (d) Terai, T.; Kikuchi, K.; Urano, Y.; Kojimad, H.; Nagano, T. Chem. Commun., 2012, 48, 2234-2236. (e) Mizukami, S.; Tonai, K.; 
Kaneko, M.; Kikuchi, K. J. Am. Chem. Soc. 2008, 130, 1437614377. (f) Giardiello, M.; Lowe, M. P.; Botta, M. Chem. Commun., 2007, 4044-4046. (g) Fanning, A.-M.; Plush, S. E.; Gunnlaugsson, T. Org. Biomol. Chem. 2015, 13, 5804-5816. (h) Balk, S.; Maitra, U.; König, B. Chem. Commun., 2014, 50, 78527854. (i) Gorai, T.; Maitra, U. ACS Sens. 2016, 1, 934-940.

13. (a) Leonard, J. P.; dos Santos, C. M. G.; Plush, S. E.; McCabe, T.; Gunnlaugsson, T. Chem. Commun. 2007, 129-131. (b) Gunnlaugsson, T.; Leonard, J. P. Dalton Trans. 2005, 19, 32043212. (c) Gunnlaugsson, T.; Leonard, J. P. Chem. Commun. 2003, 19, 2424-2425. (d) Gunnlaugsson, T.; Parker, D. Chem. Commun. 1998, 4, 511-512. (d) Nonat, A. M.; Allain, C.; Faulkner, S.; Gunnlaugsson, T. Inorg. Chem., 2010, 49, 8449-8456.

14. (a) Bradberry, S. J.; Byrne, J. P.; McCoy, C. P.; Gunnlaugsson, T. Chem. Commun. 2015, 51, 16565-16568. (b) Bonnet, C. S.; Gunnlaugsson, T. New J. Chem. 2009, 33, 1025-1030. (c) Truman, L. K.; Comby, S.; Gunnlaugsson, T. Angew. Chem. Int. Ed. 2012, 51, 9624-9627. (d) Nonat, A. M.; Quinn, S. J.; Gunnlaugsson, T. Inorg. Chem. 2009, 48, 4646-4648.

15. (a) Gunnlaugsson, T.; Leonard, J. P.; Sénéchal, K.; Harte, A. J. J. Am. Chem. Soc. 2003, 125, 12062-12063. (b) Gunnlaugsson, T.; Leonard, J. P. Chem. Commun. 2005, 3114-3131. (c) Nonat, A. M.; Harte, A. J.; Senechal-David, K.; Leonard, J. P.; Gunnlaugsson, T. Dalton Trans. 2009, 4703-4711.

16. (a) McCoy, C. P.; Stomeo, F.; Plush, S. E.; Gunnlaugsson, T. Chem. Mater. 2006, 18, 4336-4343. (b) Bradberry, S. J.; Savyasachi, A. J.; Peacock, R. D.; Gunnlaugsson, T. Faraday Discuss. 2015, 185, 413-431.

17. (a) Price, N. C. A.; Stevens, L. A. Fundamentals of Enzymology: The Cell and Molecular Biology of Catalytic Proteins; 3rd ed.; Oxford University Press: Oxford, England, 1999. (b) Lahiri, P. J. Chem. \& Cheml. Sci., 2015, 5, 389-397. (c) Lai, C. M.; Tabatabai, M. A. Soil Biol. Biochem. 1992, 24, 225-228.

18. Owing to the rapid rate of hydrolysis, it was not feasible to monitor the changes in phosphorescence at $37^{\circ} \mathrm{C}$ for quantities of enzyme $>0.08 \mathrm{U}$.

19. (a) Hulett, J. R. Q. Rev., Chem. Soc. 1964, 18, 227-242. (b) Laidler, K. J. J. Chem. Educ. 1984, 61, 494-498. (c) Upadhyay, S. K. In Chemical Kinetics and Reaction Dynamics Springer Science \& Business Media: Netherlands, 2007, p 46.

20. (a) Sizer, I. W. J. Biol. Chem. 1940, 132, 209-218. (b) Sundaram, P.; Hornby, W. FEBS Lett. 1970, 10, 325-327. (c) Huang, T.-C.; Chen, D.-H. J. Chem. Technol. Biotechnol. 1991, 52, 433-444. (d) Sahu, J. N.; Mahalik, K.; Patwardhan, A. V.; Meikap, B. C. Ind. Eng. Chem. Fundam. 2008, 47, 4689-4696. 